\title{
The One Who Got Away
}

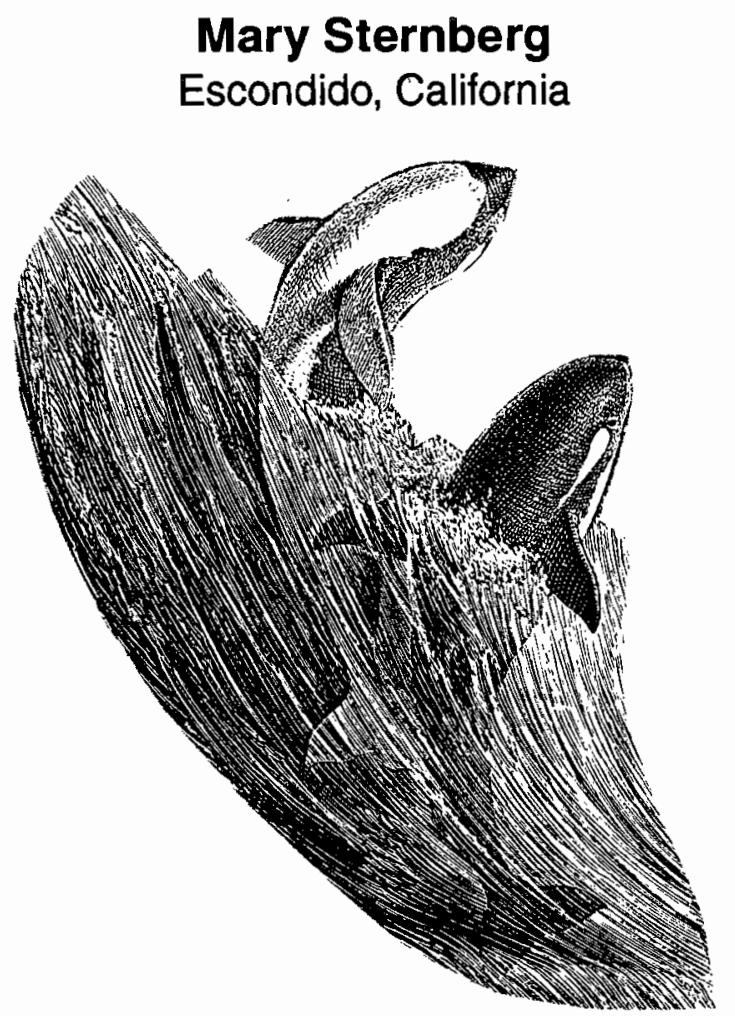

The young Orca was having trouble keeping up with the other Orcas today. There was excitement in the sea; something different was happening. He swam as fast as he could, trying to stay next to his mother, who occasionally looked back at him and prodded him on with a flip of her tail.

"What's up? Where're we going?" he asked, his tiny language squeaks almost getting lost in the excited sounds being made by the adult Orcas as they squealed and squeaked back and forth at one another while swimming towards their goal.

"You'll see when we get there," said his mother. "It's something new that some of our brothers have found-a strange creature that breathes air and can stay under water for only a short time. The Orcas say that it's real funny looking but seems to have pretty good sense. It can understand simple directions."

Now the squeals were getting louder and pretty soon, looming up ahead of them, the Orcas saw three fullgrown Orca whales. They seemed to be having fun. They were playing with something, but Sleeky, the young Orca, couldn't tell what it was. It had four long

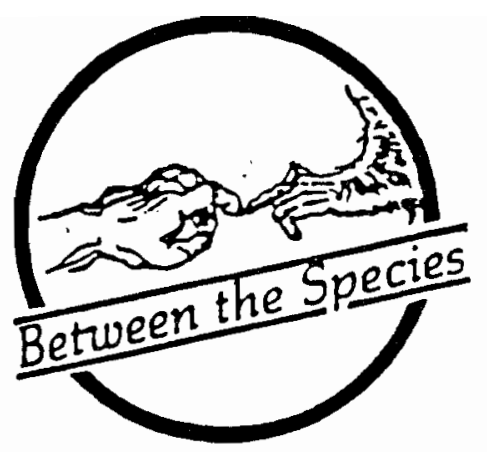

thin parts that projected from its main body. They were ugly, knobby things that seemed to flop about with no control. At the top of the body, he could make out a face with long straight hair at its top. This face, too, was ugly, kind of scary looking, he thought.

Just as Sleeky was studying it, one of the Orcas came up under the creature and with one great heave bore it on top of him out of the water. The creature held on to the Orca's flipper with two of its appendages and remained there gasping and spitting while the Orca supported him for the longest time out of water.

"What can that creature be?" asked Sleeky. "It looks scary. Will it bite or hurt us?"

"It's called a human, and when there's only one like this, they can't do us much harm. But the Orcas say they are highly dangerous in groups or even if there are only a few of them coming with their deadly machines."

"You mean they kill us?"

"Mostly they catch us and take us to prison where we are kept for life in miserable small ponds."

"But why? What have we ever done to them?"

'That's just it. We've never harmed them in any way. We even try to help them, just as the dolphins do, if they're lost or drowning in the sea by rolling them towards shore. We have tried to communicate with them, but while they have some intelligence, they aren't smart enough to grasp our language."

"It must be awful in those prisons," said Sleeky.

(C) Copyright Mary Sternberg, 1994

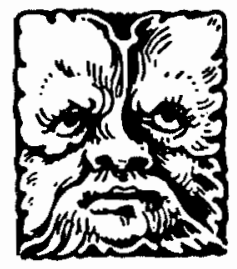


"Yes, really bad. The walls of the prisons are so confining that not only do we not have room to swim properly, but our radar systems react on us in a terrible way. The prison walls are made of something they call concrete, and when we sound our radars, they hit the walls with a deafening sound that makes our heads reverberate and ache."

As Sleeky turned to watch again, the Orca descended with the creature still gripping his flipper. The Orca spun and tilted, moving in graceful circles around the pod of Orcas, sometimes racing at high speed, then slowing almost to a stop. The creature twice lost its hold on the Orca, but the great whale would quickly turn and swim under him until he had again caught on. Whenever the creature looked as though he were ready to burst, the Orca would swiftly surface to hold it above water for a spell.

The whole thing was a most amazing performance to watch. The Orcas and some dolphins that were swimming in the area were spellbound, unaccustomed as they were to any such activity.

Curious Sleeky then returned to his mother's side and said, "But how do you get your food, and what do you do all day in such a terrible place where you can't even swim properly?"

"This is where the real horror comes in," answered his mother. "These strange creatures, who keep us captive, do it for a purpose. Just as you are interested in watching the contortions of the strange human creature we have found, they get their pleasure from training us to do all manner of stupid and unnatural tricks."

"What do you mean 'tricks'?"

"They make us leap high out of the water and jump through fiery hoops, or they make us play with a large round object called a ball and toss it with our snouts through one hoop after another. Each week they think of new tricks for us. Sometimes we pull small boats, sometimes we have to leap up to the platform of the pool and permit young humans to press their snouts against ours. This is most unpleasant since these humans have an unbelievably foul odor.

"But why don't we just refuse to do these tricks?"

"Do you like to eat, Sleeky?"

"Of course I do. What's that got to do with it?"

"If we don't do the tricks, we get no food. This is their so-called "training" method. After a day or two of no food, we're ready to do almost anything."

Suddenly another Orca, wanting to play, too, swam alongside the first Orca, and they began passing the creature back and forth to one another with their snouts. Each time, as soon as the creature began struggling for air, one of the Orcas would quickly swim to surface with him.

"Are humans just naturally mean, or are they too stupid to realize how they make us suffer in these pools?" asked Sleeky.

"A little of each," said the mother. They are mean in that they know that our lives are shortened by many years from the treatment they give us. They are stupid in that they have some strange idea that we like them despite the way they treat us."

"Is there no way out of the terrible prisons?"

"The only escape is death. On a few occasions an Orca has become so frustrated that, instead of doing a trick, he has come down hard on one of the human trainers and killed him."

"Maybe if all the trainers were killed, the humans would become afraid and stop torturing us."

"It doesn't work that way, unfortunately. Any Orca who dares to kill a human is condemned. He is taken away from the captive pod and never seen again. All the Orcas know that the humans have killed him. As valuable as we are to them, they will kill any Orca who harms a human."

"But why should there be any value in making us suffer?"

"This is one I can't understand myself, so I'm not sure how to explain it to you, but I'll try."

As she talked, several other young Orcas, about the age of Sleeky, swam in next to them, wanting to join in the excitement. After Sleeky had told them about it, they stayed close to Sleeky and his mother, circling, diving and surfacing as they kept watch on the adult Orcas who were in charge of the human.

"Humans have something that they adore and revere above everything on earth," continued the mother Orca. "They will lie for it, steal for it, even kill for it. It's called 'money,' and no matter how much of it they have, they never get enough."

"But what does this money have to do with us?"

"The ones who hold us captive are able to persuade others of their kind to part with some of their beloved money in order to come and watch us do tricks."

"If they love their money so much, how come they are willing to part with it just to see us?"

"They pretend that it's educational, which is absurd since everything they make us do is totally unnatural to us. Also, they are creatures with very little self- 
sufficiency. They must be amused fairly constantly by things outside themselves. For this 'education' and 'entertainment' they are willing to part with some of their money."

"How did you ever learn so much about these strange and fearful creatures?" asked one of the young Orcas who had joined them.

"Have you ever heard my nickname? I'm often called 'The One Who Got Away.' I was a captive for many months in one of their prison pools. One day a female human from a zoological society, places where they study animals other than themselves, came to my pool and talked with my jailers.

"The next thing I knew, I was being loaded into a narrow vat filled with water which was then placed in still another container. This last container began to roll, and I remembered having been in such containment when I was first captured.

"As we rolled along, I began to smell the wondrous smell of the sea. More and more the odor that meant home to me came to me, and I began squirming in the vat, trying to get closer to that beautiful smell.

"Soon we stopped, and the vat I was in was unloaded. The smell of the sea now was overpowering. I knew I was near to it. Could it be, were they returning me to my home?

"Sure enough, in a few moments I found myself back in the sea and began to swim with the greatest feeling of joy."

"But all was not as it appeared. I hadn't swum far when my snout struck an obstacle. It wasn't concrete this time but was soft and pliable, yet strong enough to hold me captive. I swam first one way then another. At every point I struck the soft barricade. I pushed against it as hard as I could, and while it gave somewhat to pressure, it was far too strong to break through.

"My heart sank. I knew I was still a prisoner, and this time I was all alone, something that is another kind of death sentence for an Orca."

"For many days I was in this new soft-sided pool. Humans came to feed me and one of them came several times a day, called me to the surface and examined my eyes, snout and mouth. What this one was looking for I never could figure."

"One day as I was swimming about disconsolately, a different human came. This one was female and much smaller and younger than the others. She was different, too. She would call to me, and when I surfaced, she would stroke me gently and speak her strange language quietly and soothingly. I tried to tell her how I was suffering and, although she couldn't understand my language, she seemed to understand."

"Very early the next morning she appeared again, and this time she dived into the pool with me and began feeling the barricade. She seemed to be trying to pull it to one side, but she couldn't budge it. Finally, she surfaced and went away, and I was once again alone."

"The following moming, even earlier, she was there again, this time with a shiny implement in her hand. She dived into my pool and over and over again kept slashing at the barricade with this shiny tool. She would slash, then surface for air, then come back and slash again."

"I could see that she was trying to break through the barricade, but I feared that if she didn't accomplish it soon, my jailers would come and discover her."

"Finally, when it seemed she was ready to give up, a small rent appeared in the barricade. From this she was able to make it larger and larger until soon it was big enough for an Orca to squeeze through. She pulled it aside and motioned me to go. She didn't have to motion twice. I was out of there in a flash and sending the small human many squeaks of undying gratitude."

"As you know, an Orca can always find its pod even though separated from it for a long time. I soon found mine, and here I've been ever since-The One Who Got Away."

"That human that our brothers are playing with looks pretty sick. Maybe he has taken in too much water," said Sleeky.

"I'm sure he's not only feeling sick, but he must be as frightened as I was when I was a human captive."

"Well, what are we going to do with him?" asked Sleeky.

"We're going to show him that Orcas are a lot more compassionate than humans. We're going to roll him back to land as soon as we're sure that he has fully learned what it's like to be an animal out of its element. Our hope is that he will report his experiences to others who will then set our captive Orcas free."

"Do you think they will, mother?"

"I wish I could answer 'yes.' They will probably only do it if humans begin to refuse to part with their money in order to watch us do tricks. If money can't be made on us, we'll be of no more use to the humans."

"But when will that ever be?"

"It may take a long time. Human beings think they're at the top of the evolutionary ladder, but in matters of understanding the other animals and how each is 
connected one to the other and to the universe, they have less comprehension than the tiniest mouse. Animals try to tell them and to teach them, but they rarely listen."

"But why don't they want to know about these things?"

"It would change them, and they hate change almost as much as they love money."

"What about that young one who helped you escape?"

"Thanks to our Creator for her and for others like her. They are the hope of the world."
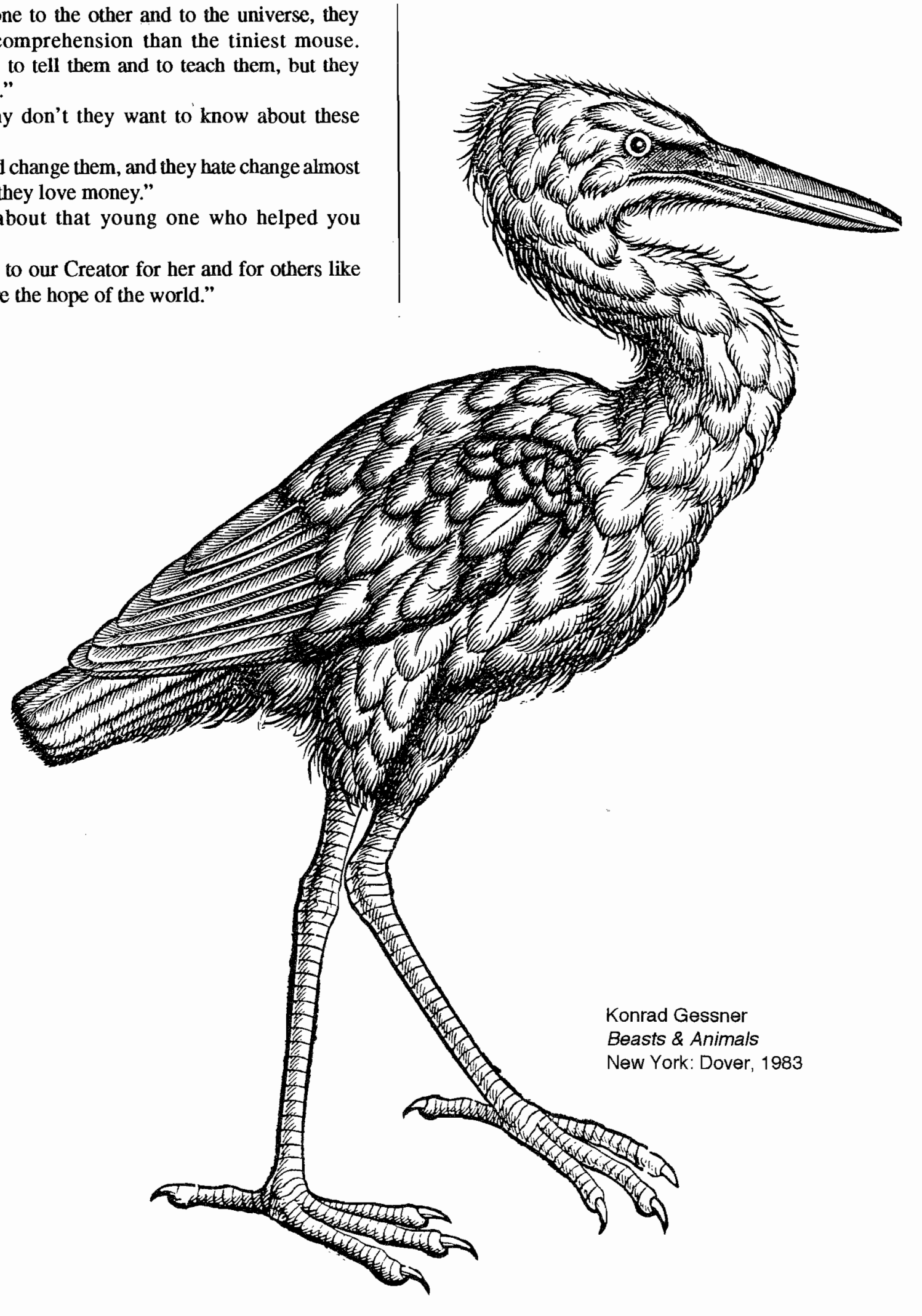

Summer \& Fall 1995

157

Between the Species 